\title{
KEDUDUKAN MAHAR DALAM PERKAWINAN
}

\section{Muhammad Ridwan}

Balai Diklat Keagamaan Palembang

mridwanbdk@gmail.com

\begin{abstract}
Abstrak
Mahar suatu Pemberian dari calon mempelai pria kepada calon mempelai wanita, baik berbentuk barang, uang atau jasa yang tidak bertentangan dengan hukum Islam. Namun mahar tidak masuk dalam ranah syarat dan rukun nikah tetapi wajib harus ada dalam perkawinan. Meski begitu, kewajiban menyerahkan mahar dari mempelai pria ke mempelai wanita ini bukan rukun dalam perkawinan. Sebab, sesuai Pasal $14 \mathrm{KHI}$ jo Pasal 2 UU Perkawinan rukun dan syarat pernikahan ada lima yakni calon suami, calon istri, wali nikah, dua orang saksi, ijab dan kabul. Namun, praktiknya mahar selalu digunakan calon pasangan suami-istri terutama yang beragama Islam, dengan ketentuan bahwa mahar atas kesepakatan dari calon suami istri. Tetapi kenyataanya di masyarakat masih ada penyimpangan bahwa dari fihak calon pengantin perempuan meminta mahar kepada calon pengantin laki-laki yang sangat memberatkan sehingga calon pengantin laki-laki tidak sanggup untuk mengadakanya yang akhirnya calon pengantin laki-laki dan perempuan mengambil jalan pintas belarian ke tempat Penghulu. Maka untuk mengungkap hal tersebut, penulis menggunakan pendekatan Penelitian Pustaka dengan metode penelitian yang dilakukan untuk mempelajari literatur-literatur dan tulisan-tulisan yang mempunyai kaitan erat dengan permasalahan yang diajukan dalam penelitian ini. Pada hal fungsi mahar adalah; a. Pembeda antara pernikahan dengan mukhadanah;, b. Bentuk penghormatan, penghargaan, dan perlindungan terhadap wanita;, c. Bentuk keseriusan laki-laki terhadap wanita yang akan dinikahinya;, d. Simbol tanggung jawab wanita terhadap mahar yang diberikan;, e. Simbol tanggung jawab pihak lakilaki, dan f. Simbol persetujuan dan kerelaan.
\end{abstract}

Kata Kunci: Mahar, Pernikahan

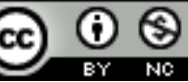

License

This work is licensed under a Creative Commons Attribution-NonCommercial 4.0 International 


\section{PENDAHULUAN}

\section{Latar Belakang Masalah}

Di zaman pra-Islam, pembayaran mahar diharuskan kepada suku atau keluarga pengantin wanita sebagai imbalan atas hilangnya kemampuan melahirkan keturunan daripadanya dan sebagai sarana untuk menciptakan kestabilan ikatan dan hubungan antara dua keluarga, telah jelas bahwa sebelum datangnya Islam pun mahar sudah diakui di Arab sebagai milik sah pengantin wanita sendiri.

Mahar merupakan pemberian yang dilakukan oleh pihak mempelai laki-laki kepada mempelai wanita yang hukumnya wajib. Dengan demikian, istilah shadaqah, nihlah, dan mahar merupakan istilah yang terdapat dalam al-Qur'an, tetapi istilah mahar lebih di kenal di masyarakat, terutama di Indonesia.

Pemberian mahar kepada wanita bukanlah sebagai harga dari perempuan itu dan bukan pula sebagai pembelian perempuan itu dari orang tuanya, pensyari'atan mahar juga merupakan salah satu syarat yang dapat menghalalkan hubungan suami isteri, yaitu interaksi timbal balik yang disertai landasan kasih sayang dengan peletakan status kepemimpinan keluarga kepada suami dalam kehidupan berumah tangga.

Kewajiban pemberian mahar oleh calon suami juga merupakan satu gambaran dari sebuah kemauan dan tanggung jawab dari suami untuk memenuhi nafkah yang jelas diperlukan dalam kehidupan berumah tangga. Yang berkewajiban memberi nafkah (mahar dan kebutuhan hidup rumah tangga) hanyalah laki-laki, karena memang menjadi kodrat bagi laki-laki bahwa la memiliki tanggung jawab dan kemampuan untuk berusaha memenuhi kebutuhan dan mencari rezeki, sedangkan tugas dari seorang wanita dalam keluarga adalah menjaga rumah tangga, terutama mendidik anak. Walau dalam kenyataannya tidak sedikit kaum perempuan yang mampu memenuhi kebutuhan rumah tangganya dengan bekerja sendiri.

Pemberian mahar saat ini kepada calon istri dilakukan dengan berbagai macam cara yang dianggap unik dan mengesankan. Salah satunya adalah membingkai mahar dalam bentuk mesjid, kapal dan lain-lain dalam sebuah bingkai kaca. Pembuatan mahar dalam bingkai kaca dengan berbagai bentuk lipatan origami sudah sangat marak diminati oleh masyarakat Indonesia, Bahkan saat ini usaha pembingkaian mahar semakin banyak peminatnya. Sungguh ironis, uang senilai ratusan ribu bahkan ada yang nominalnya sampai jutaan dibingkai secara permanen dalam sebuah bingkai kaca dan nantinya akan dipajang di dinding rumah. Uang mahar sebagai pemberian awal suami kepada istri tidak bisa digunakan lagi dan hanya bisa dipandang sebagai hiasan dinding saja. Pembingkaian ini bahkan bisa dimasukkan dalam kategori mubazir karena uang digunakan sebagai bahan origami dan dijadikan hiasan dinding. Berdasarkan uraian di atas penulis merumuskan permasalahan yaitu bagaimana kedukduan dalam Perkawinan.

2 Identifikasi Masalah

Setelah pemaparan latar belakang masalah, maka perlu untuk mengedentifikasi beberapa masalah yang timbul dan membatasi masalah masalah tersebut dengan identifikasi dan batasan masalah.sebagai berikut:

a. Hukum mahar nikah dalam islam, fiqih dan Komplikasi Hukum Islam.

b. Pendapat mazhab-mazhab dan ulama tentang mahar Batasan dan ukuran jumlah mahar nikah.

c. Mahar sebagai hak istri dan kewajiban suami. 
3 Rumusan Masalah

Adapun permasalahan dalam penelitian ini adalah Bagaimana sesungguhnya Kedudukan Mahar dalam Perkawinan

4 Tujuan Penulisan

Hasil penelitian ini sebagai jawaban permasalahan untuk mengungkap kedudukan mahar dalam perkawinan yang terkadang ditengah-tengah masyarakat menjadi debatebel. Disisi lian penelitian ini bertujuan

a. Aspek keilmuan (teoritis) Sebagai acuan bagi peneliti-peneliti lain yang ingin mengkaji masalah yang relevansinya dengan penelitian ini pada suatu saat nanti.

b. Untuk memperkaya khazanah keilmuan kalangan akademis, terutama yang mengkaji masalah yang ada relevansinya dengan penelitian ini suatu saat nanti.

\section{METODE PENELITIAN}

\section{TEMUAN DAN PEMBAHASAN}

\section{Temuan}

Mahar secara etimologi artinya mahar (maskawin). Secara terminologi, mahar ialah pemberian wajib dari calon suami kepada calon istri sebagai ketulusan hati calon suami untuk menimbulkan rasa cinta kasih bagi seorang istri kepada calon suaminya. Atau suatu pemberian yang diwajibkan bagi calon suami kepada calon istrinya, baik dalam bentuk benda maupun jasa memerdekakan, mengajar, dll(Ghazaly 2019)

Kata "mahar" berasal dari bahasa Arab yang termasuk katra benda bentuk abstrak atau masdar, yakni "Mahram" atau kata kerja, yakni fi'il dari "maharayamaharumaharan". Lalau, dibakukan dengan kata benda mufrad, yakni al-mahr, dan kini sudah diindonesiakan dengan kata yang sama, yakni mahar atau karena kebiasaan pembayaran mahar dengan mas, mahar diidentikkan dengan maskawin.(Aizid 2018)
Di kalangan fuqaha, di samping perkataan "mahar", juga digunakan istilah lainnya, yakni shadaqah, nihlah, dan faridhah yang maksudnya adalah mahar. Dengan pengertian etimologi tersebut, istilah mahar merupakan pemberian yang dilakukan oleh mempelai laki-laki kepada mempelai perempuan yang hukumnya wajib, tetapi tidak ditentukan bentuk dari jenisnya, besar dan kecilnya dalam al-Quran merupakan alHadits.

Dalam bahasa Arab, terma mahar jarang digunakan. Kalangan ahli fiqih lebih sering menggunakan kata "shidaq" dalam kitab-kitab fuqahanya. Sebaliknya, di Indonesia terma yang sering digunakan adalah terma mahar dan maskawin. Para ulama menyatakan bahwa tidak ada perbedaan mendasar antara terma ashshidaq dan terma al-mahar. Ada pendapat yang menegaskan bahwa shadaq merupakan sesuatu yang wajib karena nikah, seperti wathi' subhat, persusuan, dan menarik kesaksian. Menurut ibnu Qayyim, istilah mahar dengan shidaq tidak berbeda fungsi jika yang dimaksudkan merupakan pemberian sesuatu dari mempelai laki-laki kepada mempelai perempuan dalam sebuah perkawinan. Hanya istilah mahar digunakan untuk perkawinan, sedangkan iatilah shidaq dapat digunakan dalam hal selain perkawinan, karena adan istilahnya bersifat umum sebagaimana shadaqah wajib dan shadaqah sunnah/ shadaqah wajib adalah membayar zakat dan membayar mahar.

\section{Syarat Mahar}

Ketentuan mahar yang akan diberikan kepada calon istri setidaknya harus memenuhi syarat-syarat sebagai berikut.

a. Ada nilai Harga, Tidak sah mahar dengan yang tidak ada nilai harganya walaupun tidak ada ketentuan banyak atau sedikitnya mahar, mahar sedikit, tapi bernilai tetap sah disebut mahar.

b. Barangnya suci dan bisa diambil manfaat. Tidak sah mahar dengan diberikan berupa benda haram dan najis sepert; khamar, babi, atau darah, 
karena semua walaupun ada nilai harganya.

c. Barangnya bukan barang ghasab. Ghasab artinya mengambil barang milik orang lain tanpa seizinnya namun tidak termasuk untuk memilikinya karena berniat untuk mengembalikannya kelak. Memberikan mahar dengan barang hasilghasab tidak sah, tetapi akadnya tetap sah.

d. Bukan barang yang tidak jelas keadaannya. Tidak sah mahar dengan memberikan barang yang tidak jelas keadaannya, atau tidak disebutkan jenisnya.(Al-Juzairy 2014)

\section{Fungsi Mahar}

Islam hadir ditengah-tengah umat melindungi dan menghargai perempuan yaitu memberi hak untuk memegang usahanya. Di zaman Jahiliah hak perempuan dan dihilangkan dan disia-siakan, lalu Islam datang mengembalikan hak-hak itu. Kepadanya diberi hak mahar dan kepada suami diwajibkan memberi mahar.

Mahar adalah bagian esensial pernikahan dalam Islam. Tanpa mahar sebuah pernikahan tidak dapat dinyatakan telah dilaksanakan dengan benar. Mahar harus ditetapkan sebelum pelaksanaan akad nikah. Merupakan hak mutlak seorang perempuan untuk menentukan besarnya mahar.

Apabila mahar sudah ditentukan bentuk dan besar kecilnya, maka barang itulah yang wajib dibayarkan. Tetapi bila tidak ada ketentuan sebelumnya dan tidak disebutkan bentuknya di waktu akad nikah, maka bagi mempelai pria kepada calon mempelai perempuan, baik berupa uang, barang atau jasa yang tidak bertentangan dengan hukum Islam. Para Imam mazhab (selain Imam Malik) sepakat bahwa mahar merupakan salah satu konsekuensi adanya akad. Karena itu, akad nikah boleh dilakukan tanpa (menyebut) mahar. Apabila terjadi percampuran, ditentukanlah mahar, dan jika kemudian kemudian si istri ditalak sebelum dicampuri maka dia tidak berhak atas mahar, tetapi harus diberi mut'ah yaitu pemberian sukarela dari suami berdasarkan bentuk pakaian, cincin, dan sebagainya. Sebagaimana pendapat Abdur Rahman alJaziri mengatakan mahar berfungsi sebagai pengganti (muqabalah) istimta' dengan istrinya. Sedangkan sebagian ulama Malikiyah mengatakan bahwa mahar berfungsi sebagai imbalan jasa pelayanan seksual dan Abu Hasan Ali memposisikan mahar sebagai alat ganti yang wajib dimiliki perempuan karena adanya akad nikah.

Menurut madzab Imam syafi'i bahwa mahar tidak mengenal batas tinggi dan besarnya mahar. Segala sesuatu yang dapat menjadikan berharga bagi sesuatu yang lain dapat dijadikan mahar.(Tihami dan Sharani 2009) Begitu pula dengan Syariat Islam juga tidak menetapkan jumlah besar atau kecil mahar, karena adanya perbedaan kaya dan miskin, lapang dan sempit rezekinya. Selain itu hampir masyarakat mempunyai adat dan tradisinya sendiri. Karena itu Islam tidak menyerahkan mahar oleh sejumlah maharitu berdasarkan kemampuan masingmasing orang atau tradisi keluarganya.(Sabiq 1987)

Dalam KHI Pasal 31 dikatakan "Penentuan mahar berdasarkan asas kesederhanaan dan kemudahan yang dianjurkan oleh ajaran Islam". Pasal ini memberikan penjelasan bahwa jumlah yang dianjurkan dari mahar adalah ukuran kesederhanaan sedangkan kesederhanaan sifatnya relatif bergantung pada batas kemampuan dan kesanggupan mempelai pria.(Abdullah 1994)

Perkawinan merupakan perjanjian sakral antara calon mempelai laki-laki dengan calon mempelai wanita yang hendak membangun rumah tangga dengan tujuan keluarga yang sakinah, mawaddah warahmah. Dalam hal tersebut ajaran Islam menganjurkan kesederhanaan dan niat yang ikhlas dalam menerima hakikat perkawinan. Islam mengajarkan agar keluarga perempuan tidak menolak laki-laki yang datang untuk melamar dengan alasan kemiskinan. Dengan demikian para pemuda tidak boleh menunda perkawinan jika telah memiliki kemampuan secara material dan biologisnya sebab perkawinan hukumnya 
menjadi wajib jika sacara syahwat tidak ada kekuatan untuk menahan nafsu seksualnya.

\section{Macam-macam Mahar/maskawin}

Zumhur ulama sepakat bahwa membayar mahar itu adalah wajib. Sedangkan macam-macam mahar dapat dibedakan menjadi dua yaitu: Mahar Musamma dan Mahar Mitsil.(al-Ghofiri 2017). Untuk lebih jelasnya tentang kedua istilah tersebut di atas dapat dirinci sebagai berikut;

\section{a. Mahar Musamma}

Mahar musamma merupakan mahar yang telah jelas dan ditetapkan bentuk dan jumlahnya dalam shighat akad. Jenis mahar ini dibedakan lagi menjadi dua yaitu: Pertama Mahar Musamma Mu'ajjal, yakni mahar yang segera diberikan oleh calon suami kepada calon isterinya. Menyegerakan pembayaran mahar termasuk perkara yang sunnat dalam Islam. Kedua Mahar Musamma Ghair Mu'ajjal, yakni mahar yang telah ditetapkan bentuk dan jumlahnya, akan tetapi ditangguhkan pembayarannya.(Supriyadi dan Saebani 2015)

Terkait dengan pembayaran mahar, maka wajib hukumnya apabila telah terjadi dukhul. Ulama' sepakat bahwa membayar mahar menjadi wajib apabila telah berkhalwat (bersepi-sepian/berdua-duan) dan juga telah dukhul.

Membayar mahar apabila telah terjadi dukhul adalah wajib, sehingga jika belum terbayarkan maka termasuk utang piutang. Namun, jika sang isteri rela terhadap maharnya yang belum dibayarkan oleh suaminya. Sementara suaminya telah meninggal, maka tidak wajib ahli warisnya membayarkan maharnya. Jika isterinya tidak rela, maka pembayaran mahar itu diambilkan dari harta warisannya oleh ahli warisnya. Apabila terjadi talak sebelum terjadinya dukhul, sementara bentuk dan jumlahnya telah ditentukan dalam akad, maka wajib membayar mahar separuhnya saja dari yang telah ditentukan dalam mahar.

b. Mahar Mitsil

Mahar Mitsil adalah mahar yang jumlah dan bentuknya menurut jumlah dan bentuk yang biasa diterima keluarga pihak isteri karena tidak ditentukan sebelumnya dalam akad nikah.

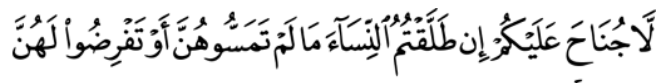

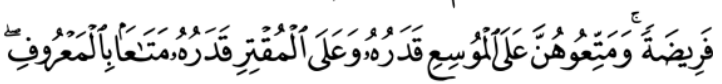

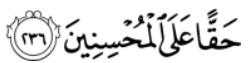

Tidak ada kewajiban membayar (mahar) atas kamu, jika kamu menceraikan isteri-isteri kamu sebelum kamu bercampur dengan mereka dan sebelum kamu menentukan maharnya. Dan hendaklah kamu berikan suatu mut'ah (pemberian) kepada mereka. Orang yang mampu menurut kemampuannya dan orang yang miskin menurut kemampuannya (pula), yaitu pemberian menurut yang patut. Yang demikian itu merupakan ketentuan bagi orang-orang yang berbuat kebajikan. (Kementerian Agama 2013)

Imam Malik menjelaskan ayat tersebut bahwa seorang laki-laki boleh memilih salah satu dari ketiga kemungkinan ada. Kemungkinan pertama, seorang suami tidak perlu membayar mahar kepada isterinya. Kemungkinan kedua, suami membayarkan mahar mitsilnya. Kemungkinan ketiga, memilih membayar mahar mitsilnya adalah keputusan yang dipandang lebih adil dan bijaksana karena disesuaikan dengan kemampuan pihak suami dan jumlah yang biasa diterima oleh pihak keluarga isteri.

\section{Pembahasan}

\section{Kedudukan Mahar Dalam Perkawinan}

Dalam Islam, disyari'atkannya membayar mahar hanyalah sebagai hadiah yang diberikan seorang lelaki kepada seorang perempuan yang dipinangnya ketika lelaki itu ingin menjadi pendampingnya, dan sebagai pengakuan dari seorang lelaki atas kemanusiaan, kemuliaan dan kehormatan perempuan. Karena itu, dalam al-Qur'an Allah telah menegaskan dalam surat an-Nisa aya

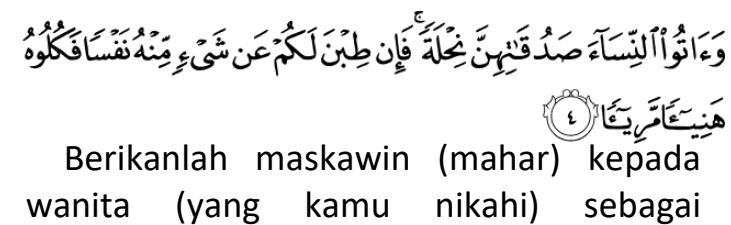


pemberian dengan penuh kerelaan. Kemudian jika mereka menyerahkan kepada kamu sebagian dari maskawin itu dengan senang hati, maka makanlah (ambillah) pemberian itu (sebagai makanan) yang sedap lagi baik akibatnya.

Pengertiannya adalah, bayarkanlah mahar kepada mereka sebagai pemberian yang setulus hati. Pemberian itu adalahmaskawin yang besar kecilnya ditetapkan atas persetujuan kedua pihak, karena pemberian itu harus dilakukan dengan ikhlas. Wajibnya mahar juga didasarkan pada sabda Rasulullah SAW )

$$
\text { التمس حديد خاتمـامن ولو العليه رواه مثفق }
$$

"Berikanlah (maharnya) sekalipun cincin besi". (HR Muttafaq 'alaih)(Sudarto 2020)

Hadits di atas menunjukkan bahwa mahar itu boleh berupa sesuatu yang bermanfaat. Di antara yang bermanfaat itu adalah mengajarkan beberapa ayat dari alQur'an. Selain mengajarkan ayat-ayat dari al-Qur'an, bentuk mahar dalam perbuatan jasa atau manfaat lainnya adalah yang termasuk dalam kategori melayani (khidmad), mereka berargumen dengan mengacu kepada firman Allah yang menceritakan perkawinan Nabi Musa a.s. dengan putri Nabi Syu'aib a.s. dengan mahar dalam bentuk jasa yang bermanfaat yaitu bekerja selama delapan tahun, QS Al Qasshas ayat 27;

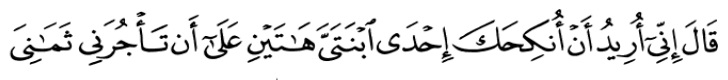

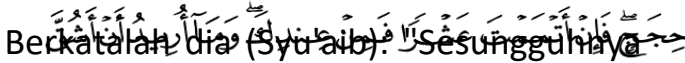

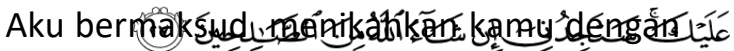
salah seorang dari kedua anaḱku ini, atas dasar bahwa kamu bekerja denganku delapan tahun dan jika kamu cukupkan sepuluh tahun Maka itu adalah (suatu kebaikan) dari kamu, Maka Aku tidak hendak memberati kamu. dan kamu insya Allah akan mendapatiku termasuk orangorang yang baik".

Mahar adalah wajib dibayar suami kepada istrinya. Namun setelah pasti ketentuan pembayarannya, tidak tertutup kemungkinan bagi pasangan suami istri yang saling mencintai dan meridhoi dan menjadi pasangan yang mesra dalam sebuah rumah tangga untuk menghadiahkan kembali mahar itu kepada suaminya demi kepentingan dan kesenangan bersama, sebab harta itu telah menjadi hartanya. Tentang hukum memberikan mahar adalah wajib, sesuai firman Allah SWT dalam Q.S. anNisa ayat 47. "Berikanlah maskawin kepada perempuan yang kamu nikahi sebagai pemberian dengan penuh kerelaan".

Ayat di atas menunjukkan bahwa Allah SWT telah memerintahkan kepada suami untuk membayar mahar kepada istrinya. Karena perintah itu tidak disertai dengan qarinah yang menunjukkan kepada sunnah ataupun mubah, maka ia menghendaki kepada makna wajib. Jadi mahar adalah wajib bagi suami terhadap istrinya, karena tidak ada qarinah yang memalingkannya dari makna wajib kepada makna yang lain.12 Pemberian tersebut juga sebagai pertanda eratnya hubungan dan cinta yang mendalam antara calon suami-istri, di samping jalinan yang seharusnya menyelimuti rumah tangga yang mereka bangun.

Di kalangan banyak orang telah menjadi tradisi bahwa mereka tidak cukup hanya dengan pemberian mahar saja, tetapi diiringi dengan aneka ragam hantaran (hadiah) lainnya, baik berupa makanan, pakaian, peralatan rumah tangga, atau yang lainnya, sebagai penghargaan dari calon suami kepada calon istri tercinta yang nantinya akan mendampingi hidupnya.

Besar dan bentuk mahar hendaknya senantiasa berpedoman kepada sifat kesederhanaan dan ajaran kemudahan yang dianjurkan Islam, sehingga besar dan bentuk mahar itu tidak sampai memberatkan calon mempelai pria.

Kalau mahar atau mas kawin itu adalah hak seorang perempuan (istri) maka istri yang baik adalah yang tidak mempersulit atau mempermahal mas kawin. Kini, tidak sedikit dari kaum muslimin yang telah teracuni paham materialisme. Mereka memandang mahar dengan pandangan materi semata. Mahar mereka jadikan sebagai asas dalam akad nikah. Padahal sebenarnya mahar hanyalah 
sebagai lambang penghormatan terhadap kaum wanita. Namun ternyata sekarang menjadi tuntutan yang paling utama. Pandangan seperti itu sangat bertentangan dengan syari'at Islam yang memerintahkan kepada pemeluknya untuk mempermudah masalah mahar. Mempermahal mas kawin adalah sesuatu yang dibenci oleh Islam, karena akan mempersulit hubungan perkawinan di antara sesama manusia. Islam tidak menyukai mahar yang berlebihlebihan (wanita yang memasang mahar terlalu mahal), bahkan sebaliknya mengatakan bahwa setiap kali mahar itu lebih murah tentu akan memberi berkah dalam kehidupan suami istri (berumah tangga).

Dan mahar yang murah adalah menunjukkan kemurahan hati si perempuan, bukan berarti malah menjatuhkan harga dirinya. Dari 'Aisyah ra. la berkata, bahwa Rasulullah Saw, bersabda:

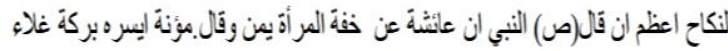

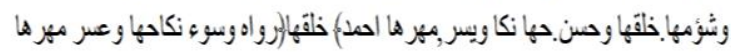

"Sesungguhnya perkawinan yang besar barakahnya adalah yang paling murah maharnya. Dan sabdanya pula: perempuan yang baik hati adalah yang murah maharnya, memudahkan dalam urusan perkawinannya dan baik akhlaknya. Sedang perempuan yang celaka yaitu maharnya mahal, sulit perkawinannya dan buruk akhlaknya". (HR. Ahmad).(uf bin Dahlan 2011)

Masih banyak manusia yang tidak mengenal mahar atau maskawin ini, mereka berpegang dengan adat Jahiliyah. Yaitu seorang ayah menyerahkan anak gadisnya kepada laki-laki yang berani memberikan jumlah mahar yang tinggi, sebaliknya menolak menyerahkan anak gadisnya kepada laki-laki yang hanya mampu memberikan mahar dengan jumlah yang sedikit. Sehingga seakan-akan perempuan itu merupakan barang dagangan yang dipasang tarif dalam etiket perdagangan itu. Perbuatan semacam ini menimbulkan banyak kegelisahan sehingga laki-laki maupun perempuan terlibat dalam bahayanya, akan menimbulkan banyak kejahatan dan kerusakan serta mengacaukan dunia perkawinan sehingga akhirnya yang halal itu lebih sulit untuk dicapai daripada yang haram (zina). Masalah nominal mahar, Islam tidak mengatur tentang berapa banyak dan sedikitnya jumlah mahar tersebut. Dalam hal ini jumlah mahar tergantung pada keadaan pihak suami serta kedudukan si istri. Kewajiban seorang muslim agar memberikan mahar atau maskawin kepada wanita yang akan dipersunting menjadi istrinya terdapat dalam al-Qur'an surat anNisa ayat 25, dan la pun mengingatkan kaum muslimin agar menikahi wanita dengan seijin walinya dan membayarkan maskawinnya.

Wahbah al-Zuhaily dalam bukunya alFigh al-Islamy wa Adillatuhu mengatakan bahwa mahar yang disepakati oleh pengantin lakilaki dan perempuan yang disebutkan dalam redaksi akad sesudahnya. Berdasarkan definisi tersebut, dapat dimengerti bahwa penetapan jumlah mahar telah ditentukan ketika akad nikah, akan tetapi diperbolehkan untuk membayar secara penuh sekaligus atau melakukan penundaan. Hal ini tentunya sangat didukung oleh kerelaan kedua belah pihak.(Al-Zuhaili, t.t.) Hal-hal yang termasuk dalam ke dalam mahar musamma dalam akad adalah apa saja yang diberikan oleh suami untuk istrinya menurut adat yang berlaku sebelum pesta pernikahan ataupun sesudahnya, seperti gaun pengantin atau pemberian yang diberikan sebelum dukhul (bersetubuh) atau sesudahnya. Karena yang ma'ruf (baik) dalam masyarakat seperti yang disyaratkan dalam akad adalah lafdziyah (yang dilafalkan atau diucapkan).

Pemberian itu wajib disebutkan pada saat akad, suami harus menyebutkan kecuali bila disyaratkan untuk tidakmenyebutkan dalam akad. Sedangkan mahar yang tak ditentukan adalah merupakan mahar yang diberikan oleh calon suami kepada calon istrinya yang ketentuan besar kecilnya belum ditetapkan dan bentuknya juga tidak disebutkan. Akan 
tetapi mahar ini disesuaikan dengan kedudukan wanita dalam struktur kehidupan sosial dari segala aspek atau pertimbangan seperti keagamaan, kekayaan, kecantikan, kepandaian, kesopanan, usia, kegadisan, kejandaan, negeri, keturunan, dan kemuliaan leluhurnya. Mahar mitsil itu diukur dari perempuan yang menyerupai istri dari seluruh kerabatnya, baik dari pihak ayah maupun ibunya.

Seperti saudara kandung, bibi dari pihak ayah, anak paman dari pihak ayah, bibi dari pihak ibu dan selain mereka dari kerabat yang ada. Jumlah mahar atau maskawin yang wajar itu akan tergantung pada kedudukan seseorang dalam kehidupannya, status sosial, pihak-pihak yang menikah itu, dan dapat berbeda dari satu tempat dengan tempat yang lainnya, dari satu masa ke waktu yang lain dan dari satu negeri dengan negeri yang lain.20 Jenis mahar yang dipakai masyarakat Indonesia secara umum adalah mahar musamma, biasanya ditetapkan bersama atau dengan musyawarah dari kedua belah pihak.

Berapa jumlahnya dan bagaimana bentuknya harus disepakati bersama, dan sunnah tatkala mengucapkan ijab kabul pernikahan, agar para saksi dapat mendengar secara langsung jumlah dan bentuk dari mahar tersebut. Penentuan mahar serta pemberiannya baik dengan cara memberi kontan atau menangguhkannya adalah suatu hal yang diperbolehkan, akan tetapi ketentuan dari mahar musamma ini telah ditetapkan ketika ijab kabul pernikahan. Keputusan musyawarah antara kedua belah pihak dapat menjadi tolak ukur pemberian mahar secara kontan ataupun penundaan.

\section{PENUTUP}

\section{Simpulan}

Mahar merupakan pemberian wajib dari calon suami kepada calon istri sebagai ketulusan hati calon suami untuk menimbulkan rasa cinta kasih bagi seorang istri kepada calon suaminya. Atau suatu pemberian yang diwajibkan bagi calon suami kepada calon istrinya, baik dalam bentuk benda maupun jasa. Agama tidak menetapkan jumlah minimum dan begitu pula jumlah maksimum dari mahar. Hal inidisebabkan oleh perbedaan tingkatan kemampuan manusia dalam memberikannya. Mahar boleh dilaksanakan dan diberikan dengan kontan atau utang, apakah mau dibayar kontan sebagian dan utang sebagian. Oleh karenanya mahar memiliki fungsi a. Pembeda antara pernikahan dengan mukhadanah;, b. Bentuk penghormatan, penghargaan, dan perlindungan terhadap wanita; c. Bentuk keseriusan laki-laki terhadap wanita yang akan dinikahinya; d. Simbol tanggung jawab wanita terhadap mahar yang diberikan;, e. Simbol tanggung jawab pihak laki-laki, dan f. Simbol persetujuan dan kerelaan baru yang merupakan esensi dari temuan penelitian.

\section{Rekomendasi}

Dari hasil penelitian tersebut perlu direkomendasikan kepada pengampu Fiqh Munakahat untuk menyampaikan bahwa yang selama ini masyarakat memahami mahar(maskawin) adalah seolah-olah rukun dan tekadang memberatkan, maka melalui tulisan ini bisa memberikan jawaban bahwa mahar tidak ada ketentuan yang pasti yang penting ada nilai ekonomis, sederhana dan bermanfaat. 


\section{DAFTAR PUSTAKA}

Abdullah, Abdul Gani. (1994). Pengantar Kompilasi Hukum Islam dalam Tata Hukum Indonesia. Gema Insani.

Aizid, Rizem. (2018). Fiqh Keluarga Terlengkap. LAKSANA.

Al-Juzairy, Abdurrahman. (2014). Al-Fiqh 'ala al-Mazahib al-Arba'ah. Kairo: Dar al-Jauzy.

Al-Zuhaili, Wahbah. t.t. DR., al Figh al Islamy Wa Adillatuhu. Bairut, Dar al Fikr, cet. IV.

Dahlan, Djamaludin Arra uf bin. (2011). Aturan Pernikahan Dalam Islam. Lembar Langit Indonesia.

Ghazaly, H. Abdul Rahman. (2019). Fiqh munakahat. Prenada Media.

Ghofiri, Hafidz al-. (2017). "Konsep besarnya mahar dalam pernikahan menurut Imam As-Shafi'i." PhD Thesis, IAIN Ponorogo.

Kementerian Agama, R. I. (2013). “Tafsir Alqur'an The Great Miracle." Solo. PT Tiga Serangkai Pustaka Mandiri.

Sabiq, Sayyid. (1987). "Fiqh Sunnah, terj." Kamaluddin A. Marzuki. Bandung: Al Ma'arif.

Sudarto, M. Pd I. (2020). FIKIH MUNAKAHAT. Penerbit Qiara Media.

Supriyadi, Dedi, dan Beni Ahmad Saebani. (2015). “Fiqh Munakahat Perbandingan: dari tekstualitas sampai legitimasi."

Tihami, H. M. A., dan Sohari Sharani. (2009). Fikih Munakahat, Kajian Fikih Nikah Lengkap. Jakarta: PT.” Raja Grafindo Persada. 